岩石鈗物鉿床学会誌

49 巻 2 号, 1963 年

\title{
COEXISTING FELDSPARS IN SOME METAMORPHIC ROCKS OF JAPAN
}

\author{
Nobuhide Murakami \\ Institute of Earth Science, Faculty of Literature and Science, \\ Yamaguchi University, Yamaguchi \\ and \\ Shigeyoshi Kubota \\ Okayama Factory, Shinagawa Hakurenga Co. Ltd., Okayama
}

\section{INTRODUCTION}

Feldspar is useful in determining the metamorphic condition. It is well known that the plagioclase becomes more calcic and coexisting potash feldspar more sodic with advancing metamorphism. Barth (1951) used the molar fraction Or in potash feldspar, and later (1956) the value of ratio of $\mathrm{Ab}$-fraction in potash feldspar to $\mathrm{Ab}$-fraction in coexisting plagioclase, as a geologic thermometer, but the effects of water pressure and rock pressure were not considered at all. As predicted by Orville (1960), in the formation of metamorphic feldspar, a high pressure has the same effect as that of a low temperature.

The degree of ordering in potash feldspar may also be useful in geologic thermometry as discussed by Heier (1957) and MacKenzie (1957). Heier (1957) and Shidô (1958) found that the transition from monoclinic to triclinic symmetry in potash feldspar takes place in the lower zone of amphibolite facies or in the upper zone of granulite facies in progressive metamorphism. In an experimental work by MacKenzie (1957), both temperature and water pressure had an effect on the ordering of $\mathrm{Al}-\mathrm{Si}$ atoms in artificial albite.

It is very difficult to elucidate the condition of formation of feldspar, but much information will be gained by the studies on the chemistry, crystal structure, and field occurrence of the mineral as discussed in this paper.

\section{METHODS OF INVESTIGATION}

1) Rocks were crushed into the size of 100 to 150 mesh.

2) Potash feldspar was separated by means of a magnetic 
separater and heavy liquid.

3) The $\mathrm{K}$ and $\mathrm{Na}$ contents of potash feldspar were determined chemically by the aid of a flame photometer, and the An content of coexisting plagioclase was determined optically.

4) The optical angle of potash feldspar was determined on the universal stage.

5) The value of $2 \theta_{131}-2 \theta_{1 \overline{3} 1}(\mathrm{CuK} \alpha)$ of plagioclase and triclinicity of potash feldspar were determined by the aid of an X-ray diffractometer.

\section{DESCRIPTION OF FELDSPARS}

Twenty-five specimens studied by the writers and six specimens by other workers are described here. They were collected from the main regional metamorphic zones and some contact-metamorphic zones in Japan.

a) Sambagawa metamorphic zone

Two specimens collectes by Dr. K. Hide from the Shirataki Mine area in Shikoku, were studied. They are considered to belong to epidote-amphibolite facies, mineralogically.

SS-1: Muscovite-quartz schist, Main const.; quartz, albite, potash feldspar, muscovite, biotite, garnet.

SS-2: Muscovite-quartz schist, Main const.; quartz, albite, potash feldspar, muscovite, biotite, epidote.

b) Ryôke metamorphic zone

Eleven specimens of banded gneiss and associated migmatite were collected from the Yanai area, Yamaguchi Prefecture, and banded gneiss from Hase area, Nara Prefecture.

1) Yanai area

YR-1 and RY-2 occur in the transition zone, while RY 3-10 in the migmatite zone, according to Nureki (1960). It is considered that the latter zone is higher in metamorphic grade than the former.

RY-1: Banded gneiss, Main const.; quartz, plagioclase, potash feldspar, biotite, muscovite, cordierite.

RY-2: Biotite gneiss, Main const.; quartz, plagioclase, potash feldspar, biotite, muscovite, cordierite.

RY-3: Banded gneiss, Main const.; quartz, plagioclase, potash feldspar, biotite, muscovite.

RY-4: Banded gneiss, Main const., quartz, plagioclase, potash feldspar, muscovite, cordierite, sillimanite, almandine.

RY-5: Banded gneiss, Main const.; quartz, plagioclase, potash 
Table 1. Feldspars from some regional metamorphic rocks in Japan

\begin{tabular}{|c|c|c|c|c|c|c|}
\hline \multirow{2}{*}{$\begin{array}{l}\text { Specimen } \\
\text { No. }\end{array}$} & \multicolumn{3}{|c|}{ Potash feldspar } & \multicolumn{2}{|c|}{ Plagioclase } & \multirow[b]{2}{*}{$\begin{array}{c}\text { References \& } \\
\text { comments }\end{array}$} \\
\hline & $\begin{array}{c}\text { Or } \\
(\mathrm{mol} \text { per cent })\end{array}$ & $2 \mathrm{Vx}$ & Triclinicity & $\begin{array}{c}\text { An content } \\
(\text { shell part })\end{array}$ & $\left(\begin{array}{cc}2 \theta & 131 \\
& 2 \theta_{131} \\
(\mathrm{Cu} & \mathrm{K} a)\end{array}\right.$ & \\
\hline $\begin{array}{ll}\text { SS } & -1 \\
\text { SS } & -2\end{array}$ & $\begin{array}{l}96.2 \\
95.7\end{array}$ & $\begin{array}{l}72-87 \\
68-84\end{array}$ & $\begin{array}{l}0.92 \\
0.88\end{array}$ & $\begin{array}{l}2 \\
2\end{array}$ & $\begin{array}{l}1.07 \\
1.08\end{array}$ & New data \\
\hline $\begin{array}{l}\text { RY -1 } \\
\text { RY -2 } \\
\text { RY - 3 } \\
\text { RY -4 } \\
\text { RY -5 } \\
\text { RY -6 } \\
\text { RY -7 } \\
\text { RY -8 } \\
\text { RY -9 } \\
\text { RY -10 } \\
\text { RN -1 }\end{array}$ & $\begin{array}{l}90.7 \\
92.2 \\
92.2 \\
85.3 \\
86.1 \\
85.3 \\
87.5 \\
88.7 \\
90.6 \\
92.3 \\
85.1\end{array}$ & $\begin{array}{l}51-54 \\
50 \\
56-62 \\
55-66 \\
55-64 \\
56-62 \\
59 \\
52-69 \\
59 \\
47-62 \\
57-71\end{array}$ & $\begin{array}{c}0 \\
0 \\
0 \\
\text { (131) diff. } \\
\text { (131) diff. } \\
0.13 \\
0 \\
0 \\
0 \\
0 \\
0\end{array}$ & $\begin{array}{l}34 \\
35 \\
34 \\
32 \\
33 \\
14 \\
34 \\
34 \\
35 \\
32 \\
32 \\
32\end{array}$ & $\begin{array}{l}1.55 \\
1.73 \\
1.68 \\
1.70 \\
= \\
1.75 \\
1.78 \\
= \\
=\end{array}$ & $\begin{array}{l}\text { " } \\
" 1 \\
" 7 \\
" \prime \\
" 1 \\
" 1 \\
" 1 \\
" 1 \\
" 1\end{array}$ \\
\hline $\begin{array}{l}\mathrm{RA}-1 \\
\mathrm{RA}-2\end{array}$ & $\begin{array}{l}80.9 \\
87.9\end{array}$ & $\begin{array}{l}48-58 \\
67\end{array}$ & $\begin{array}{l}0 \\
0\end{array}$ & $\begin{array}{l}29 \\
25\end{array}$ & - & $"$ \\
\hline $\begin{array}{l}\text { RH -1 } \\
\text { RH -2 } \\
\text { RH - 3 }\end{array}$ & $\begin{array}{l}86.8 \\
89.1 \\
86.2\end{array}$ & $\begin{array}{l}45 \\
41-58 \\
43\end{array}$ & $\begin{array}{l}0 \\
0 \\
0\end{array}$ & $\begin{array}{l}21 \\
26 \\
25\end{array}$ & $\underline{-}$ & $\begin{array}{l}" \prime \\
" \prime\end{array}$ \\
\hline $\begin{array}{l}H K-1 \\
H K-2 \\
H F-1 \\
H S-1 \\
H S-2\end{array}$ & $\begin{array}{l}88.7 \\
84.4 \\
82.5 \\
86 \\
83\end{array}$ & $\begin{array}{c}68-78 \\
62-82 \\
68-72 \\
- \\
-\end{array}$ & $\begin{array}{l}0.38 \\
0.48 \\
0.20 \\
0.73 \\
0.70\end{array}$ & $\begin{array}{l}20 \\
20 \\
20 \\
- \\
-\end{array}$ & $\begin{array}{l}\bar{z} \\
\bar{z}\end{array}$ & $\begin{array}{c}" \prime \\
" \prime \\
\text { Shimazu (1959) } \\
\prime \prime\end{array}$ \\
\hline
\end{tabular}

feldspar, biotite, muscovite, sillimanite.

RY-6: Coarse-grained banded gneiss, Main const.; quartz, plagioclase, potash feldspar, biotite, muscovite, cordierite (pinnitized).

RY-7-10: Migmatite, Main const.; quartz, plagioclase, potash feldspar, biotite, muscovite.

2) Hase area

RN-1: Banded gneiss, Main const.; quartz, plagioclase, potash feldspar, biotite, muscovite, sillimanite, almandine.

The feldspars in this rock are similar to those from the Yanai area as described in Table 1.

c) Abukuma metamorphic zone

RA-1: Banded gneiss, Main const.; quartz, plagioclase, potash feldspar, biotite, cordierite, sillimanite, almandine.

RA-2: Banded gneiss, Main const.; quartz, plagioclase, potash feldspar, muscovite.

RA-1 and RA-2 occur in zones $C$ and $B$, respectively, according to Miyashiro (1958). The feldspars in these rocks are similar to those in the Ryôke metamorphic rocks. The potash feldspar in zone $\mathrm{C}$ is 
monoclinic, but Shidô (1958) found the occurrence of triclinic potash feldspar in the lower-grade metamorphic rocks from the Iritono area which belongs to the same metamorphic zone.

d) Hidaka metamorphic zone

RH-1: Banded gneiss, Main const., quartz, plagioclase, potash feldspar, biotite, muscovite, sillimanite.

RH-2: Migmatite, Main const., quartz, plagioclase, potash feldspar, biotite.

RH-3: Migmatite, Main const., quartz, plagioclase, potash feldspar, biotite, muscovite.

As shown in Table 1, the feldspars occurring in this zone are similar to those in the Ryôke metamorphic zone. Triclinic potash feldspar have not yet been found from this zone (Hunahashi and Hashimoto, 1951 ; etc.).

e) Hida metamorphic zone

HK-1: Banded gneiss; Main const., quartz, plagioclase, potash feldspar, biotite, titanite.

HK-2: Banded gneiss, Main const., quartz, plagioclase, potash feldspar, biotite, chlorite, muscovite.

HF-1: Augen gneiss, Main const., quartz, plagioclase, potash feldspar, biotite.

HS-1: Banded gneiss, HS-2: Gneissose granodiorite

HS-1 and HS-2 are reported by Shimazu (1959).

As shown in Table 1, the potash feldspars are microcline of high triclinicity value and have comparatively high Or contents, while the coexisting plagioclases are sodic to intermediate oligoclase. These properties in feldspars are characteristic to this zone, as described by other workers (Kobayashi, 1958, etc.).

f) Some contact metamorphic zones

Table 2. Feldspars from some contact metamorphic rocks in Japan

\begin{tabular}{|c|c|c|c|c|c|c|}
\hline \multirow{2}{*}{$\begin{array}{l}\text { Specimen } \\
\text { No. }\end{array}$} & \multicolumn{3}{|c|}{ Potash feldspar } & \multicolumn{2}{|c|}{ Plagioclace } & \multirow{2}{*}{$\begin{array}{c}\text { References \& } \\
\text { comments }\end{array}$} \\
\hline & $\begin{array}{c}\text { Or } \\
\text { (mol per cent })\end{array}$ & $2 V x$ & Triclinicity & $\begin{array}{l}\text { An content } \\
\text { (shell part) }\end{array}$ & $\begin{array}{l}2 \theta_{131^{-}} \\
2 \theta_{131}\end{array}$ & \\
\hline $\mathrm{CA}-1$ & 75.1 & $59-64$ & 0 & 35 & 1.66 & New data \\
\hline $\begin{array}{ll}\text { CF } & -1 \\
\text { CI } & -1 \\
\text { CI } & -2 \\
\text { CI } & -3 \\
C T & -1 \\
\text { CH }-1 \\
\text { CH }-2\end{array}$ & $\begin{array}{l}81.1 \\
87 \\
81 \\
79 \\
76 \\
83.0 \\
83.8\end{array}$ & $\begin{array}{l}57-77 \\
66 \\
61 \\
72 \\
72 \\
52 \\
54\end{array}$ & $\begin{array}{l}0-0.71 \\
0.12 \\
0.12 \\
0 \\
0 \\
0 \\
0\end{array}$ & $\begin{array}{c}24 \\
35 \\
31 \\
37 \\
10-20 ? \\
21 \\
21\end{array}$ & $\begin{array}{l}\overline{ } \\
\overline{-} \\
\overline{2.05} \\
1.54\end{array}$ & $\begin{array}{c}\text { Shimazu (1958) } \\
" \prime \\
\text { Kuroda (1958) } \\
\text { New data. }\end{array}$ \\
\hline
\end{tabular}


CA-1: Cordierite-biotite hornfels from the environs of Arakawa-goya, Saitama Prefecture (Ishii, 1961). Main const., quartz, plagioclase, potash feldspar, biotite, cordierite.

This rock, metamorphosed by the intrusion of quartz diorite, may belong to pyroxene-hornfels facies. The potash feldspar having monoclinic symmetry is highly sodic and plagioclase in equilibrium with potash feldspar is sodic labradorite as described by Ishii (1961). CF-1: Sillimanite-biotite hornfels from Irawara, Fukuoka Prefecture (Murakami and Fujimoto, 1955). Main const, quartz, plagioclase, potash feldspar, biotite, muscovite, andaluite, cordierite, sillimanite.

This rock metamorphosed by the Irawara granodiorite, may belong to amphibolite facies. The potash feldspar having both monoclinic and triclinic symmetry in one specimen is moderately potassic, and coexisting plagioclase is calcic oligoclase to sodic andesine.

CI-1: Sandstone hornfels from Akka, Iwate Prefecture (Shimazu, 1958, 1959). Main const., quarz, plagioclase, potash feldspar, biotite, muscovite, sillimanite.

CI-2: Banded hornfels from the same locality. Main const., quartz, plagioclase, potash feldspar, biotite, muscovite, cordierite, sillimanite, almandine.

CI-3: Banded gneiss from the same locality. Main const. quartz, plagioclase, potash feldspar, biotite, muscovite, cordierite, sillimanite.

These rocks were contact-metamorphosed by the Tanohata granodiorite.

Shimazu (1958) studied the geology of this district in detail and later (1959) described the feldspars in the metamorphic rocks which resembled those from the Irawara region, as shown in Table 2.

The peculiar interesting facts observed in the feldspars are as follows: (i) The potash feldspar becomes more sodic at the contact with granodiorite mass, while plagioclase does not become regularly more calcic but becomes more or less sodic in the highly hydrotherma$11 y$ metamorphosed rocks (banded gneiss and banded hornfels). (ii) The potash feldspar in sandstone hornfels has monoclinic symmetry, while those in banded hornfels and banded gneiss have triclinic symmetry.

CT-1: Sillimanite-quartz schist from the Tanzawa Mountainland, Kanagawa Prefecture (Kuroda, 1958, 1960). Main const., quartz, plagioclase, potash feldspar, biotite, muscovite, sillimanite, andalusite.

This rock was contact-metamorphosed by the Tanzawa quartz 
diorite. Kuroda (1958) described the potash feldspar in it and later (1960) reported a geological study of this mountainland. As shown in Table 2 the potash feldspar having monoclinic symmetry is highly sodic, while coexisting plagioclase is a sodic to intermediate oligoclase.

CH-1: Biotite hornfels from Masago, Shimane Prefecture. Main const., quartz, plagioclase, potash feldspar, biotite.

$\mathrm{CH}-2$ : Homblende-biotite hornfels from Otsu Island, Yamaguchi Prefecture. Main const., quartz, plagioclase, potash feldspar, biotite, hornblende.

These rocks were contact-metamorphosed by the Cretaceous Hiroshima granite. The potash feldspars having monoclinic symmetry are potassic, while coexisting plagioclases are oligoclase.

\section{Characteristic Features of Feldspars from the Respective Metamorphic Zones}

\section{a) Sambagawa metamorphic zone}

The potash feldspar is highly potassic, showing high triclinicity. The plagioclase is highly sodic, highly ordered but not perfectly. The potash feldspar of high triclinicity was also found by Kanehira and Banno (1960) in the Sambagawa crystalline schist from the Iimori area, Kii peninsula.

The above-described features are more or less similar to those in authigenic feldspars* described by Baskin (1956), though the authigenic feldspars are more potassic and show monoclinic symmetry in many samples.

b) Ryôke, Hidaka and Abukuma metamorphic zones

The potash feldspar is potassic and becomes more sodic with advancing metamorphism. It is monoclinic to triclinic with small triclinicity value.

The inversion from triclinic to monoclinic symmetry is recognized in the higher grade zone of the Abukuma metamorphic zone, while in the Yanai area of the Ryôke metamorphic zone, the inversion from monoclinic to triclinic symmetry is recognized in the higher grade metamorphic zone. In the Hidaka zone the triclinic potash feldspar is not recognized in any metamorphic rocks.

The plagioclase becomes more calcic with advancing metamorphism in the Abukuma zone (Miyashiro, 1958; Shido, 1958), while in

* They are considered to have been crystallized at the lowest temperature. 
the Hidaka zone and Yanai area, it becomes more sodic from banded gneiss zone to migmatite zone, and more calcic from hornfels zone to banded gneiss zone, with advancing metamorphism.

c) Hida metamorphic zone

Potash feldspar is potassic, showing moderate to high triclinicity. Plagioclase is sodic to intermediate oligoclase.

d) Contact-metamorphic zones from Arakawa-goya, Tanzawa Mountainlind

Potash-feldspar is sodic, showing monoclinic symmetry. Plagioclase is sodic labradorite, while sodic oligoclase in the Tanzawa Mountainland.

e) Contact-metamorphic zones from the Irawara, Akka, Masago, and Ôtsu Island.

Potash feldspar is potassic, showing monoclinic to triclinic symmetry. Plagioclase is intermediate oligoclase to sodic andesine.

Some Constiderations on the Condition of Formation of Metamorphic Feldspars

a) The relation between chemical composition and metamorphic condition in potash feldspar

Barth (1952) considered that the Or-fraction in potash feldspar is a function of temperature of its formation, on the basis of exsolution principle. But, the exact form of solvus in natural potash feldspar remains still unknown because of very slow chemical reaction in the experimental works (Tuttle and Bowen, 1958). Increase in the Or content with advancing metamorphism was found in the Adirondack area by Engel and Engel (1960), as predicted by Barth (1952). Orville (1960) found that K-rich feldspars are replaced by Na-rich feldspars at the higher temperature or lower pressure in the experimental study on alkali feldspar-alkali chloride hydrothermal ion exchange, but the uplift of the solvus which has an effect on Or content in synthetic potash feldspar under high water pressure is negligibly small as clarified by Yoder et al (1957).

From the above facts, it is concluded that metamorphic potash feldspar becomes more potassic with rising temperature, and the effect of water pressure is comparatively small though it has a reverse effect as compared to temperature, provided that the $\mathrm{Ca}$ and $\mathrm{Ba}$ contents which give effect on the form of solvus are almost the same in any potash feldspars.

b) The relation between degree of ordering and metamorphic 
condition in potash feldspar

In potash feldspar, maximum microcline is assumed to be fully ordered, orthoclase half ordered, and sanidine fully disordered, and the degree of ordering is given by the value of triclinicity (Goldsmith and Laves, 1954). A hypothetical diagram illustrating the relation between triclinicity and temperature and water pressure in potash feldspar, is constructed on the basis of the following experimental data (Fig. 1). Mackenzie (1957) found that the lattice parameter of synthetic albites has a steady value which is characteristic to the temperature of crystallization, but at the low water pressure and/or low temperature the high or intermediate form will metastably crystallize because of insufficient energy to accelerate the ordering of $\mathrm{Al}$ and $\mathrm{Si}$ atoms. In this case the water pressure which accelerates the ordering of atoms to the same degree for a limited time can be lower at lower temperature, as the time to make the lattice parameter to the same degree at a definite water pressure is shorter at the lower temperature. The above-mentioned characters in albite can be applied to the natural potash feldspar, as shown in Fig. 1, in which the boundary line between orthoclase and microcline can be shifted to the right side, that is, high temperature side, with prolonged heating in metamorphism. The boundary between the temperature of crystallization of stable orthoclase and that of microcline is estimated between $500^{\circ}$ and $600^{\circ} \mathrm{C}$ after Goldsmith and Laves (1954), and Euler und Hellner (1961). The temperature of crystallization of stable maximum microcline is supposed to be below about $450^{\circ} \mathrm{C}$, for the maximum microcline occurring in the metasomatic syenites is supposed to be in equillibrium with the

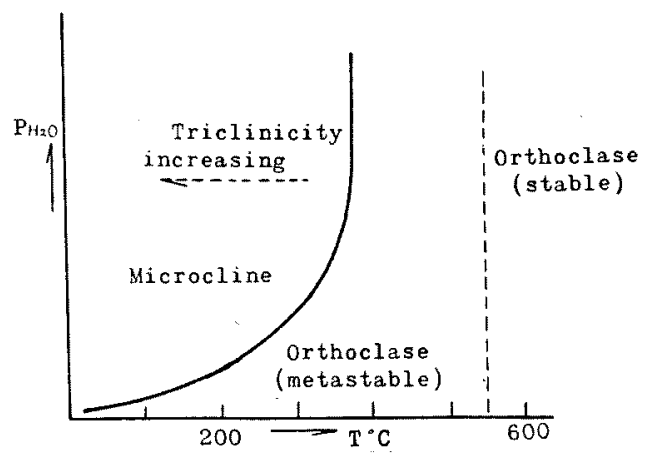

Fig. 1. Schematic diagram illustrating the relation between crystal structure and condition of formation of potash feldspar. 
perfectly ordered albite which is stable only below $450^{\circ} \mathrm{C}$ (Murakami, 1960), though the presence of Na-feldspar in solid solution may more of less lower the temperature of formation of stable microcline as discussed by Smith (1960).

c) The relation between chemical composition and metamorphic condition in plagioclase

From some field works in metamorphic terrain, it has been considered that the plagioclase can be more calcic with increasing temperature, but increasing water pressure may have the same effect as decreasing temperature, as is the case with potash feldspar.

d) The relation between the tie line connecting plagioclase with coexisting potash feldspar in the An-Ab-Or diagram, and their metamorphic condition

Yoder et al. (1957) considered that the trend of the tie line is closely related to the conditions of crystallization in igneous rocks. In metamorphic rocks the tie line may have a higher angle with $\mathrm{Ab}-\mathrm{Or}$ side at higher temperature and lower angle at lower temperature. The higher or lower water pressure will have the same effects as those of lower or higher temperature, respectively.

Fig. 2 shows the tie lines of the coexisting feldspars from some metamorphic rocks in which the conditions of formation are different from each other.

(a) Muscovite-quartz schist from the Sambagawa metamorphic zone which is considered to belong to epidote-amphibolite facies:

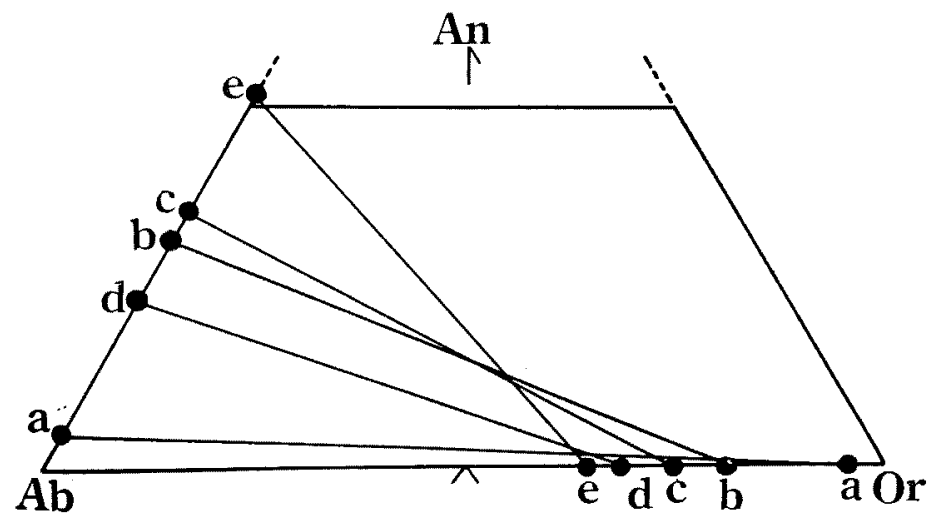

Fig 2. Diagram illustrating the relation between chemical compositions of potash feldspars and those of associated plagioclases from some metamorphic rocks in which the conditions of formation are clearly different from each other. 
Low temperature and highest water pressure (Miyashiro, 1961).

(b) Sillimanite-biotite gneiss from the Abukuma metamorphic zone which is considered to belong to amphibolite facies: Moderate temperature and more or less low water pressure (Hayama, 1956; Miyashiro, 1961).

(c) Cordierite-biotite hornfels from Arakawa-goya which is considered to belong to pyroxene-hornfels facies: High temperature and low water pressure.

(d) Leptite from Madras, India (Naidu, 1955), which is considered to belong to granulite facies: High temperature and high water pressure.

(e) Sanidinite from Laacher See district, Germany (Chudoba, 1931), which is considered to belong to sanidinite facies: Highest temperature and lowest water pressure.

As shown in this figure, the potash feldspars are more sodic with increasing temperature, while plagioclases are more calcic except for the feldspar from leptite which is considered to have been crystallized under high water pressure. This fact suggests that water pressure may give a larger effect on the composition of plagioclase than on that of potash feldspar.

Other similar examples can be cited as follows:

(1) RY-6 in Table 1 is a coarser-grained banded gneiss with more ordered potash feldspar and suffering more severe hydrothermal metamorphism than other banded gneisses. It is obvious that this rock was formed at higher water pressure. The plagioclase in it is

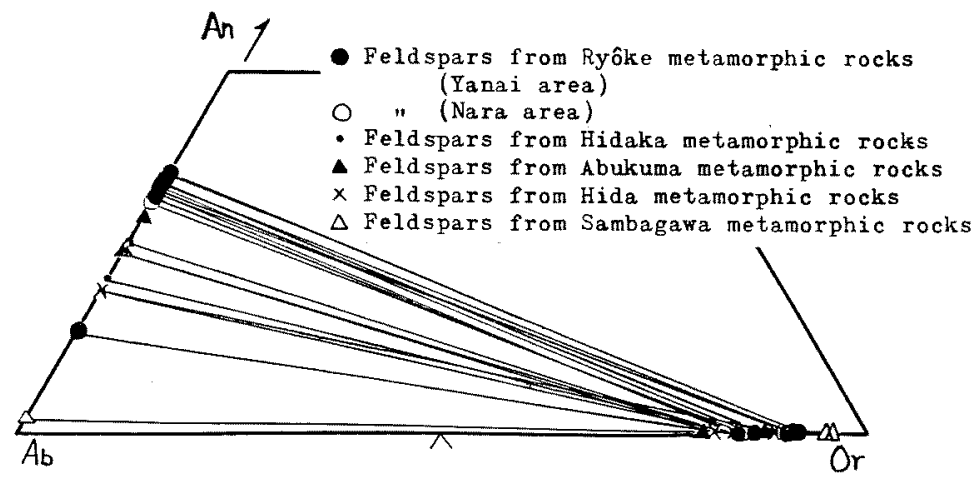

Fig. 3. Diagram illustrating the relation between chemical compositions of potash feldspars and those of associated plagioclases from some regional metamorphic rocks in Japan. 
highly sodic, while coexisting potash feldspar is not so potassic.

(2) As already-mentioned, the plagioclases in the hydrothermally metamorphosed rock from the Akka contact metamorphic zone are more sodic, while coexisting potash feldspars are comparatively potassic.

From the above-described data it is supposed that the water pressure has a larger effect on the composition of plagioclase than on the composition of potash feldspar. Thus it is considered that the trend of the tie lines at high temperature and low water pressure, or at high temperature and high water pressure, can be different from those at low temperature and low water pressure or low temperature and high water pressure, respectively.

\section{Conditions of Formation of Some Metamorphic ROCKS IN JAPAN}

From the above description it is considered that the temperature and water pressure of formation of different metamorphic rocks can be estimated relatively, provided that an equillibrium in chemical compositions of the feldspars has been established, without changing the compositions subsequent to the time of their formation, and the length of metamorphism has been almost the same. Thus

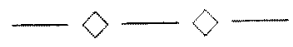

Fig. 4. Diagram illustrating the relation between Or contents and optical angles in potash feldspars from some regional metamorphic rocks in Japan. Symbols are the same as in Fig. 3.

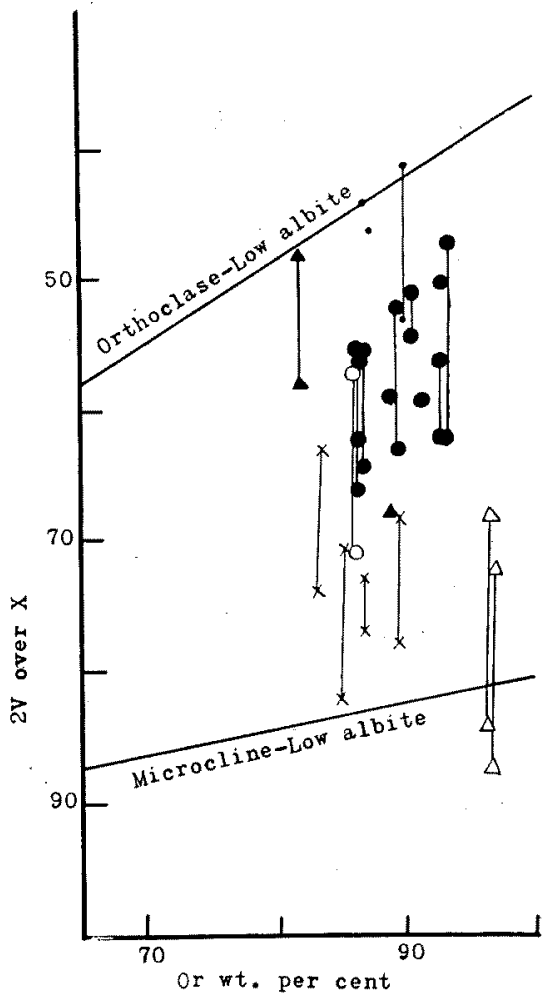




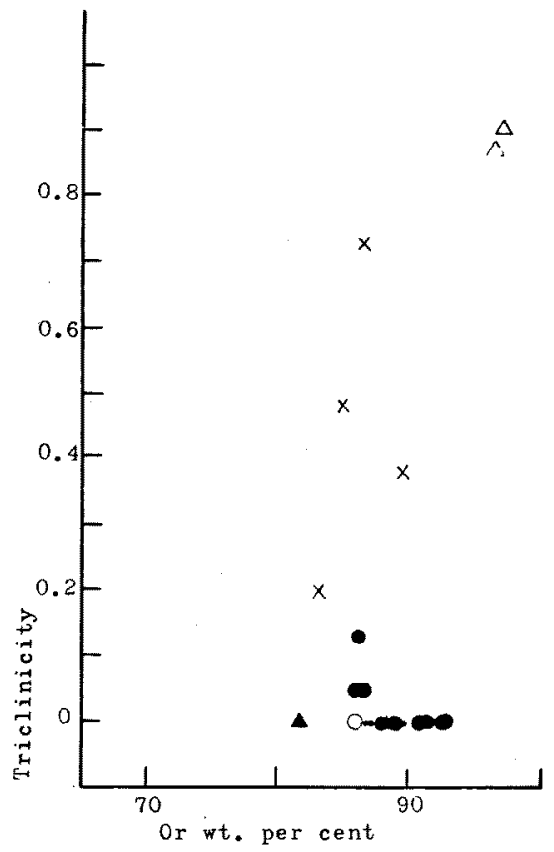

Fig. 5. Diagram illustrating the relation between Or contents and triclinicity in potash feldspars from some regional metamorphic rocks in Japan. Symbols are the same as in Fig. 3.

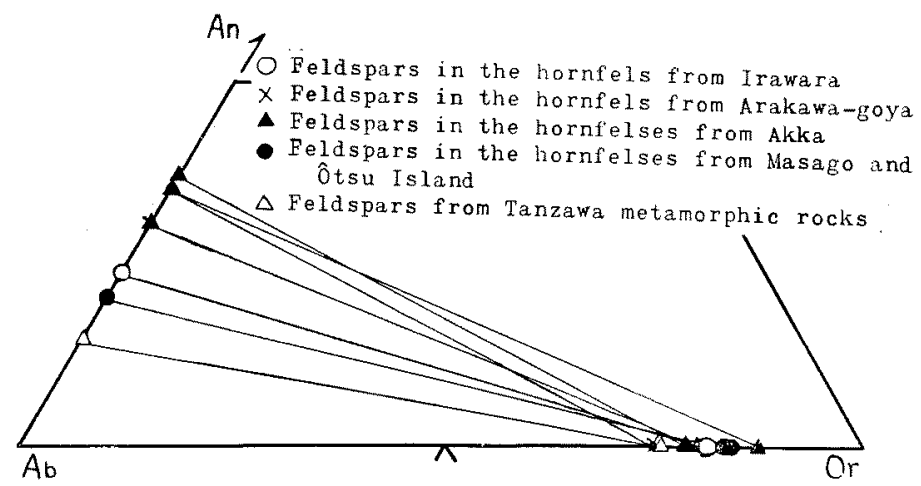

Fig. 6. Diagram illustrating the relation between chemical dompositions of potash feldspars and those of associated plagioclases from some contact metamorphic rocks in Japan. 
the regional metamorphic zones in Japan can be divided into three types by their metamorphic conditions estimated from the features of the feldspars in this paper.

a) Sambagawa type: Lowest temperature and highest water pressure.

It is characterized by the occurrence of highly potassic potash

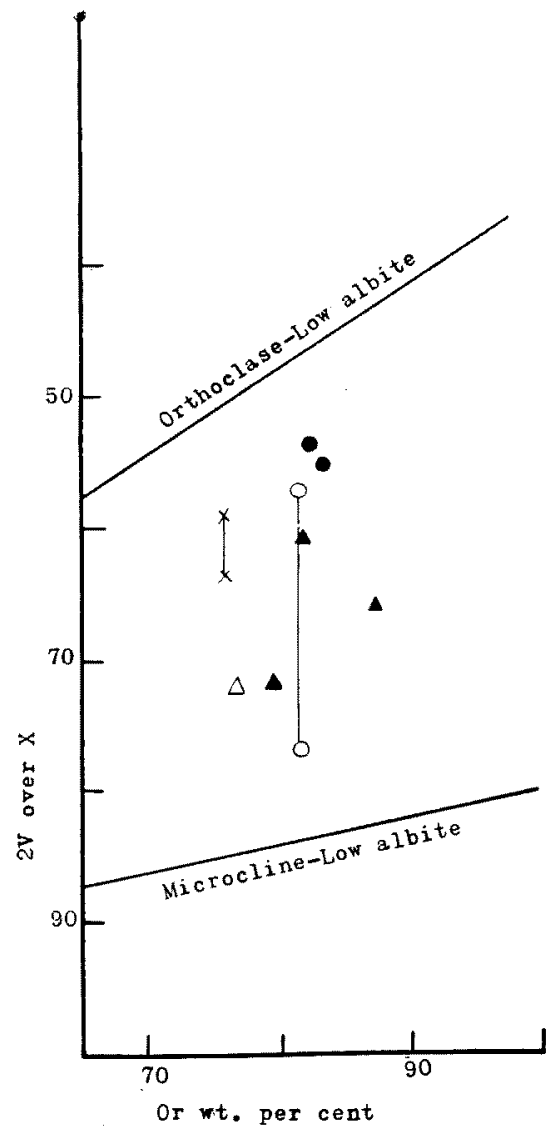

Fig. 7. Diagram illustrating the relation between or contents and optical angles in potash feldspars from some contact metamorphic rocks in Japan. Symbols are the same as in Fig. 6.

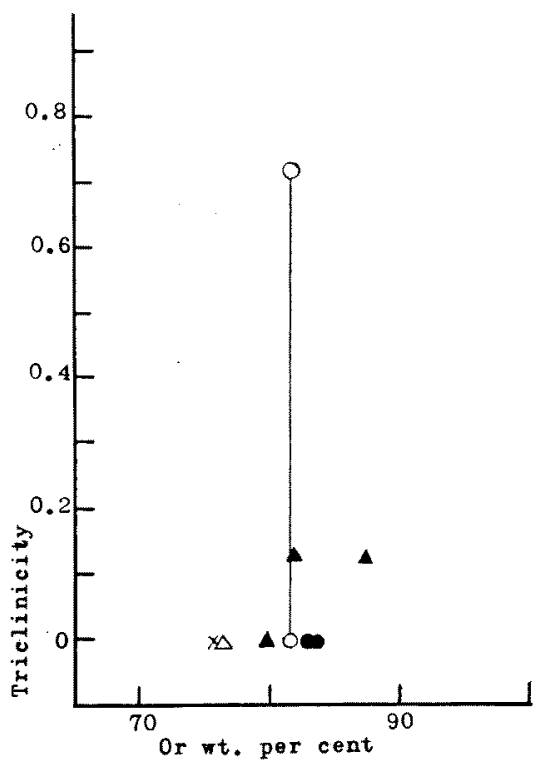

Fig. 8. Diagram illustrating the relation between Or contents and triclinicity in potash feldspars from some contact metamorphic rocks in Japan. Symbols are the same as in Fig. 6 . 
feldspar with high triclinicity value, and highly sodic plagioclase.

b) Hida type*: Low? to moderate temperature and high water pressure.

It is characterized by the occurrence of moderately potassic potash feldspar with medium to high triclinicity value, and oligoclasic plagioclase.

c) Ryôke, Abukuma, and Hidaka types: Low to moderate temperature and low water pressure.

It is characterized by the occurrence of moderately potassic potash feldspar with monoclinic symmetry or low triclinicity value, and oligoclasic to andesinic plagioclase. In the Abukuma zone, it is inferred that the water pressure would have been more or less higher than in other zones, because of the occurrence of microcline in the lower grade metamorphic zone, while in the Hidaka zone the water pressure would have been lower than in other zones, because of the absence of microcline.

The correlation of the temperature and water pressures in the three types of regional metamorphic zones is schematically shown in

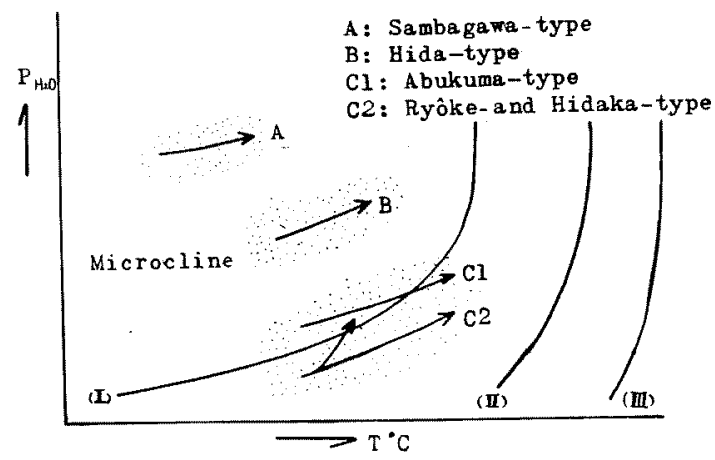

Fig. 9. Schematic diagram illustrating the relative relations of the temperatures and water pressures of formation in three types of regional metamorphic zones in Japan. (I), (II) and (III) represent the boundaries between orthoclase and microcline in the Ryôke-Hidaka-Abukuma metamorphic rocks, Hida metamorphic rocks, and Sambagawa metamorphic rocks, respectively.

* The kyanite-bearing schist occurs in the northeastern area of this zone (Kobayashi, 1958). This rock is supposed to have been formed at lower temperature and higher water pressure than other rocks. 
Fig. 9.

The conditions of some contact-metamorphic rocks described in this paper are inferred as follows:

1) Cordierite-biotite hornfels from Arakawa-goya: High temperature and low water pressure.

2) Hornfelses from Akka, Irawara, Masago, and Otsu Island: Moderate temperature and low to moderate water pressure.

3) Sillimanite-quartz schist from Tanzawa Mountainland: High temperature and high water pressure.

\section{ACKNOWLEDGEMENTS}

The writers express their thanks to Professor T. Tomita of Kyûshu University for invaluable help and encouragement. Thanks are also accorded to Dr. K. Hide of Hiroshima University, Dr. Y. Okamura of Yamaguchi University and Mr. M. Ishii of Tôkyô Civil Engineering Research Institute for kind offer of some metamorphic rock specimens. A part of the expenses for this study is supplied by the Department of Education as Research Fund for Natural Science.

\section{REFERENCES}

Barth, T.F.W. (1951), The feldspar geologic thermometers. Neues Jahrb. f. Min., 82, 143-154.

(1956), Studies in gnesiss and granite. Skr. norsk. Vid. -Akad., 1. Mat. -Nat. Klasse, 1, 1-35.

Baskin, Y. (1956), A study of authigenic feldspars. Jour. Geol., 64, 132-155.

Chudoba, K. (1931), Über die Feldspate der Sanidinite aus dem Laacher Seegebiet. Neuse Jahrb. f. Min., 34, 443-475.

Engel, A.E.J. and C.G. Engel (1960), Progressive metamorphism and granitization of the major paragneiss, northeast Adirondack Mountains, New York. Part II. Mineralogy. Bull. Geol. Soc. Am., 71, 1-57.

Euler, E. \& E. Hellner (1961), Hydrothermale und röntogenographische Untersuchungen an gesteinsbildenden Mineralen. VI. Über hydrothermale hergestellten triklinen K-Feldspat. Zeitschr. Krist., 115, $433-438$.

Ferguson, R.B. (1960), The low-temperature phases of the alkali feldspars and their origin. Canada. Min, 6, 415-438.

Goldsmith J.R. and F. Laves, (1954a). The microcline-sanidine stability relations. Geochim. Cosmochin. Acta, 5, 1-19.

- $(1954 \mathrm{~b})$, Potassium feldspar structurally intermediate between sanidine and microcline. Geochim. Cosmochin. Acta, 6, $100-118$. 
Hayama, Y. (1956), Role of water-vapour pressure in metamorphism (in Japanese). Chikyu Kagaku, 26-27, 19-28.

Heier, K.S. (1957), Phase relations of potash feldspar in metamorphism. Jour. Geol., 65, 468-479.

Hide, K. (1961), Geologic structure and metamorphism of the Sambagawa crystalline schists of the Besshi-Shirataki Mining district in Shikoku, Southwest Japan (in Japanese). Geol. Rep. Hiroshima Univ., 9, 1-87.

Hunahashi, M. and S. Hashimoto (1951), Geology of the Hidaka zone, Hokkaido (in Japanese). Monograph Assoc. Geol. Collad., 6, 1-38.

Ishii, M. (1961), Contact phenomena of the quartz-dioritic stock in the environs of Arakawa-goya, Saitama Prefecture, with special reference to the formation of sandstone-origin hornfels with igneous-like texture (in Japanese). Chikyn̂-Kagaku, 55, 9-16.

Kanehira, K. and S. Banno (1960), Ferriphengite and aegirinjadeite in a crystalline schist of the Iimori district, Kii Peninsula. Jap. Jour. Geol. Geogr., 66, 654-659.

Kawai, N. and T. Nozawa (1958), Explanatory text of the geological map of Japan. Higashimozumi sheet. 1:50000. Geol, Surv. Japan.

Kuroda, Y. (1958), Notes on some soda-potash feldspars in the metamorphic rocks, Japan. Sci. Rep. Tokyo Kyôiku Daigaku, Ser. C, 57, $117-126$.

(1960), Geology of the Tanzawa-mountainland with special reference of the metamorphic rocks of the northern part (in Japanese). Jour. Geol. Soc. Japan, 66, 700-709.

Kobayashi, H. (1958), Hida metamorphic belt (in Japanese). Jubilee Pub. Commemor. Prof. J. Suzuki 60th Birthday, 123-140.

Mackenzie, W.S. (1957), The crysyal modification of $\mathrm{NaAlSi}_{3} \mathrm{O}_{8}$. Am. Jour. Sci., 255, 481-516.

Miyashiro, A. (1958), Regional metamorphism of the Gosaisho-Takanuki district in the Central Abukuma Plateau. Jour. Fac. Tôkyô Univ. Sec. II, 11, 219-272.

(1961), Evolution of metamorphic belts. Jour. Petr., 2, 277-311.

Murakami, N. and S. Fujimoto, (1957), Geology and petrography of the southern part of the Takawa metamorphic zone, North Kyûshû (in Japanese). Jour. Jap. Assoc. Min. Petr. Econ. Geol., 41, 16t-171.

(1960), Temperature of syenitization of granite and some related problems (in Japanese). Jour. Geol. Soc. Japan, 67, 237-248.

Naidu, P.R.J. (1955), Minerals of charnockite from India. Schiweiz. Min. Petr. Mitt., 34, 203-280.

Noble, D.C. (1962), Plagioclase unmixing and the lower boundary of the amphibolite facies. Jour. Geol., 70, 234-239.

Nozawa, $\mathrm{T}$. and H. Isomi (1958), Explanatory text of the geological map of Japan. Funatsu sheet. 1:50000. Geol. Surv. Japan.

Nureki, T. (1960), Structural investigation of Ryôke metamorphic rocks of the area between Iwakuni and Yanai, Southwest Japan. Jour. Sci. Hiroshima Univ. Ser, C. 3, 69-141.

Okamura, Y. (1960), Structural and petrological studies on the Ryôke 
gneiss and granodiorite complex of the Yanai district, Southwest Japan. Jour. Sci. Hiroshima Univ, Ser, C, 3, 143-213.

Orville, P.M. (1960), Alkali-feldspar-alkali-chloride hydrothermal ion exchange. Year Book Carnegie Inst, Washington, 59, 104-108.

Shido, F. (1958), Plutonic and metamorphic rocks of the Nakoso and Iritono districts in the Central Abukuma Plateau. Jour. Fac. Sci. Tôkyô Univ., Sec. II, 11, 131-217.

Shimazu, M. (1958), On the thermally metamorphosed rocks surrounding the Tanohata granite, Northern Kitakami Mountainland (in Japanese). Jour. Geol. Soc. Japan, 64, 109-124. (1959), Potash feldspars in some metamorphic rocks (in Japanese). Jour. Jap. Assoc. Min. Petr. Econ. Geol., 43, 185-193.

Smith, J.V. and W.S. MacKenzie (1958), The alkali feldspars IV: The cooling history of high-temperature sodium-rich feldspars. Am. Mineral., 43, 872-889.

- (1960), Phase diagrasm for alkali feldspars. 21st Intern. Geol. Congr., 21, 185-193.

Tuttle, O.F. and N.L. Bowen (1958), Origin of granite in the light of experimental studies in the system $\mathrm{NaAlSi}_{3} \mathrm{O}_{3}-\mathrm{KAlSi}_{3} \mathrm{O}_{8}-\mathrm{SiO}_{2}-\mathrm{H}_{2} \mathrm{O}$. Mem. Geol. Soc. Am., 74.

Yoder, H.S., et al. (1957), Ternary feldspars. Year Book Carnegie Inst. Washington, 56, 206-214.

\section{本邦産 $2 \cdot 3$ の変成岩中の共存長石}

村上 允英・父保田惠涁

要 約

長石の鉣物学的研究は最近著しく進み，その結果を利用すればそれを舍む岩石の生成 条件を或程度推定出来ると考えられる。筆者等は本邦の主要北域变成带及び $2 \cdot 3$ の接触 变成鱼より座する変成岩中のカリ長石及び共存する斜長石についてその化学組成・結晶 䅅造を調へ，生成条件を推定した。その結果は次の通り；三波川変成岩類：最低温度・最

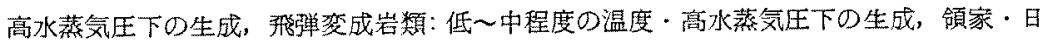

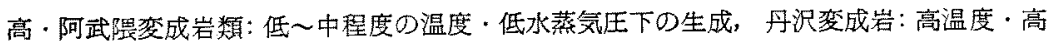

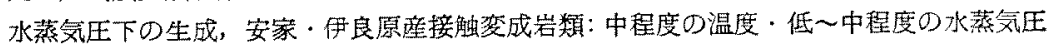
下の生成，秋父芫川小屋接触変成岩：高温度・低水蒸気压下の生成，広岛花菵岩に上り接 触变成岩: 中程度の温度・中程度の水蘶気圧下の生成。 